\title{
Empirical relationships between compressive and flexural strength of concrete containing recycled asphalt material for pavement applications using different specimen configurations
}

\author{
(1)C.R. Marín-Uribe $\ltimes,{ }^{(1)}$ R. Navarro-Gaete \\ School of Civil Construction. Pontificia Universidad Católica de Chile, (Santiago, Chile) \\ crmarin@uc.cl
}

Received 21 September 2020

Accepted 27 January 2021

Available on line 20 May 2021

\begin{abstract}
The flexural strength of pavement concrete is generally deduced by testing beams or by applying empirical equations. In this investigation, concrete mixtures were manufactured, incorporating 0, 20, 50 and 100\% Reclaimed Asphalt Pavement (RAP), by weight, as a replacement for natural aggregates. The compressive strength was measured using cubic specimens and the flexural strength was measured for three types of specimens; beam, semicircular (SCB) and modified beam. This study proposes logarithmic and power equations that allow the estimation of the flexural strength of a concrete mix that incorporates RAP as a function of its compressive strength. Linear or power models are proposed to predict beam flexural strength from SCB specimens and a logarithmic model for modified beam specimens. Statistical analyses show that the proposed prediction models can be considered sufficiently accurate and their use is justified.
\end{abstract}

KEYWORDS: Concrete; Reclaimed Asphalt Pavement (RAP); Flexural strength; Compressive strength; Semicircular beam.

Citation/Citar como: Marín-Uribe, C.R.; Navarro-Gaete, R. (2021) Empirical relationships between compressive and flexural strength of concrete containing recycled asphalt material for pavement applications using different specimen configurations. Mater. Construcc. 71 [342], e249. https://doi.org/10.3989/mc.2021.11520.

RESUMEN: Relaciones empíricas entre la resistencia a compresión y a flexión de hormigones para pavimentos, fabricados con material asfáltico recuperado, empleando distintas configuraciones de probeta. La resistencia a la flexión de un concreto para pavimentos generalmente se estima ensayando vigas o aplicando ecuaciones empíricas. En esta investigación se fabricaron mezclas de concreto incorporando 0, 20, 50 y 100\% de material asfáltico recuperado (RAP) como reemplazo por peso de los agregados naturales. Se midieron las resistencias a la compresión de probetas cúbicas y a la flexión para tres tipos de probetas; viga, semicircular ( $\mathrm{SCB}$ ) y viga modificada. Este estudio propone ecuaciones logarítmica y potencial para estimar la resistencia a la flexión de un concreto que incorpora RAP en función de su resistencia a la compresión. Para predecir la resistencia a la flexión de viga a partir de probetas SCB se propone el modelo lineal o potencial y para probetas de viga modificada el modelo logarítmico. Los análisis estadísticos muestran que los modelos de predicción propuestos pueden considerarse lo suficientemente precisos y su uso está justificado.

PALABRAS CLAVE: Hormigón; Material asfáltico recuperado (RAP); Resistencia a la flexión; Resistencia a la compresión; Viga semicircular.

Copyright: (C2021 CSIC. This is an open-access article distributed under the terms of the Creative Commons Attribution 4.0 International (CC BY 4.0) License. 


\section{INTRODUCTION}

Flexural strength is a measure of the tensile strength of a concrete and is expressed in terms of the Modulus of Rupture (MOR). This parameter is used in structural design (1), quality control and acceptance of pavements (2), which is determined by the standard methods given in ASTM C78 (third-point loading) or ASTM C293 (center-point loading) using a standardized 150 x 150 x $550 \mathrm{~mm}$ beam. However, this test is susceptible to the effects of sample preparation, handling, and the curing process (2). Also, the specimen is heavy, making it difficult to handle in the laboratory or the field (3). Many road agencies have used compressive strength as they consider it to be more reliable and convenient to analyze the quality of the concrete and, later through correlation, estimate its flexural strength. Although it is known that this relationship is not a direct proportion, it is commonly held that the compressive strength is approximately ten times the flexural strength, which implies a fixed relationship between these two variables (4). Previous investigations have proposed empirical equations for this relationship, mainly of the form $f_{s}=a f_{c u}{ }^{n}$, where $f_{s}$ is the flexural strength of the concrete, $f_{c u}$ is the cube compressive strength of the concrete and $a$ and $n$ are correlation coefficients, as shown in Table 1. Most of these equations follow the square root form as an exponent (5-7). Other investigations have proposed equations that do not follow the square root form to predict the flexural strength of concrete (3, $8-10$ ). It should be noted here that, in the equations in ACI-2002 and ACI-2005, a conversion factor of 0.8 is applied to convert the compressive strength of the cylinder to the cube, according to (11).

TABLE 1. Empirical relationship between flexural strength and compressive strength of cubes.

\begin{tabular}{lll}
\hline \multicolumn{1}{c}{ Equation } & \multicolumn{1}{c}{ Comment } & Reference \\
\hline$f_{s}=0.7 \sqrt{f_{c u}}$ & IS: $456-2000$ (India) & (3) \\
\hline$f_{s}=0.201 f_{c u}$ & EC-02 (Europe) & (3) \\
\hline$f_{s}=0.45 f_{c u}{ }^{2 / 3}$ & Ahmed et al. & (4) \\
\hline$f_{s}=0.554 \sqrt{f_{c u}}$ & ACI-2002 & ACI-2005 \\
\hline$f_{s}=0.462 \sqrt{f_{c u}}$ & A) \\
\hline
\end{tabular}

On the other hand, about $86 \%$ of Chile's paved road network is built with hot mix asphalt (HMA) (12). One of the most commonly used procedures for the rehabilitation of these pavements is the milling of their asphalt layers, producing reclaimed asphalt pavement material (RAP), which is stored or sent to landfill. This material can be re-processed in plant and separated into different sizes, usually into a fine fraction that passes the No. 4 sieve $(4.75 \mathrm{~mm})$ and a coarse fraction represented by the material retained on the No. 4 sieve (13). Although restricted in the amount to be incorporated, its use has focused primarily on producing new hot mix asphalt (HMA) and warm mix asphalt (WMA) as a replacement for natural virgin aggregates. For example, in Texas, U.S. RAP is limited to 10,20 , and $30 \%$ replacement in the surface, mid and base layers, respectively $(14,15)$. In Chile, the Ministry of Public Works limited the incorporation of RAP for HMA to $20 \%$ replacement (16).

In recent years, the incorporation of RAP in the manufacture of new concrete mixtures for pavements has been explored with two main objectives: to achieve greater dissipation of fracture energy, by reducing a possible abrupt and fragile failure of the concrete, and reducing the exploitation of natural resources, by promoting a lower consumption of virgin aggregates using a material that still retains good physical properties and is considered to be an artificial source of aggregates $(17,18)$. There is previous research regarding the effects of RAP on the mechanical properties of concrete. In general, there is evidence that the addition of RAP negatively impacts on the fundamental mechanical properties of concrete, such as its compressive strength (19-23), flexural and splitting tensile strength (24-28), and the modulus of elasticity $(21-23,29)$.

Based on the literature review, it was possible to establish that there is no consensus for estimating flexural strength from compressive strength. There are proposals for various equations that provide different results. Few laboratory studies have been carried out to propose a user-friendly correlation equation to estimate the modulus of rupture of concrete incorporating RAP, as a substitute for natural virgin aggregates in pavement applications. The main objective of this study was to characterize concrete mixtures with different RAP contents in the laboratory, measuring the compressive strength of cubes and the flexural strength by testing three types of specimens; beam, semi-circular beam (SCB), and modified beam. The results of this research propose different empirical equations to estimate the flexural strength of concrete with RAP from its cubic compressive strength, according to the type of test specimen. It also proposes correlation equations for estimating the modulus of rupture of concrete with RAP for a standardized beam, from laboratory results using the semicircular and modified beam specimens.

Road agencies in Chile will be able to use the results of this research to study the possible adoption of the use of concrete with RAP aggregates for pavements in its construction standards, by applying the precepts of the circular economy, promoting the reduction of construction waste, reducing the use of natural resources and limiting energy consumption. This study also promotes the feasibility of using other 
geometries and test modes, such as SCB, to estimate the modulus of rupture of concrete by implementing a simple, fast test with different advantages compared to the traditional beam test.

\section{MATERIALS}

A commercial Portland cement type A, with a density of $2.9 \mathrm{~g} / \mathrm{cm}^{3}$, and fresh tap water were used for all concrete mixtures. This water is considered suitable for use in concrete under the standard NCh1498 (30). The fine and coarse virgin aggregates used in this research conformed to the requirements for concrete aggregates. Table 2 shows the combined gradation of the aggregate; this remained constant for RAP's different replacement rates of virgin aggregates. The physical properties of the aggregates used in this investigation are shown in Table 3 . The RAP used in this research was from a section of urban highway in Santiago de Chile. The RAP was processed in a hammer crusher and separated into two sizes: a fine fraction, represented by the material passing the No. 4 sieve $(4.75 \mathrm{~mm})$, and a coarse fraction, represented by the material retained in the No. 4 sieve. The fine and coarse aggregates of RAP contained $7 \%$ and $4 \%$ asphalt by weight, respectively. It is worth noting that the RAP material was not washed before its use in the concrete mixtures.

\section{EXPERIMENTAL METHODS}

\subsection{Mixing Design and Mixing Procedures}

A grade $\mathrm{H} 35$ concrete $(35 \mathrm{MPa})$ was dosed according to NCh 170 (31), the minimum recommended by the Code Standards and Technical Specifications of Paving Works of the Ministry of Housing and Urban Planning for concrete pavements (32). To investigate the different effects of RAP on concrete properties, four groups of concrete mixtures with different RAP contents were prepared: $0 \%$ (control), $20 \%, 50 \%$ and $100 \%$ replacement of fine and coarse aggregate, by weight. These mixtures were designated R0, R20, R50, and R100, respectively. A total of four mixtures were prepared, one for each RAP content. For determining the proportions of the materials in the mixtures, the modified Faury method was used. Table 4 shows the proportions in the mixtures studied. In all mixtures, $160 \mathrm{~kg} / \mathrm{m}^{3}$ of water was used and the water to cementitious material ratio of 0.44 was kept constant. The concrete mixtures were prepared using a mechanical mixer and compacted by a vibrating table. The samples were cured in immersion, to guarantee the correct hydration of cementitious materials until they were tested at a temperature of $23 \pm 2^{\circ} \mathrm{C}$ in accordance with that recommended by $\mathrm{NCh} 1017$ (33).

TABLE 2. Aggregate gradation.

\begin{tabular}{lcccccccccccc}
\hline Sieve size $(\mathrm{mm})$ & 40 & 25 & 20 & 12.5 & 10 & 5 & 2.5 & 1.25 & 0.63 & 0.315 & 0.16 & 0.08 \\
\hline \% passing & 100 & 76 & 62 & 53 & 47 & 32 & 25 & 20 & 15 & 6 & 1 & 0 \\
\hline
\end{tabular}

TABLE 3. Properties of aggregates.

\begin{tabular}{lcccccc}
\hline Property & Unit & Sand & Gravel 1 & Gravel 2 & Fine RAP & Coarse RAP \\
\hline Bulk unit weight & $\mathrm{t} / \mathrm{m}^{3}$ & 2.74 & 2.80 & 2.76 & 2.30 & 2.40 \\
\hline Dry bulk specific gravity & $\mathrm{t} / \mathrm{m}^{3}$ & 2.58 & 2.66 & 2.68 & 2.24 & 2.31 \\
\hline Relative specific gravity (SSD) & & 2.64 & 2.71 & 2.71 & 2.26 & 2.35 \\
\hline Absorption & $\%$ & 2.30 & 1.90 & 1.00 & 1.10 & 1.55 \\
\hline Asphalt content & $\%$ & - & - & - & 7.0 & 4.0 \\
\hline
\end{tabular}

TABLE 4. Mix proportions for $35 \mathrm{MPa}$ concrete comprising virgin aggregate and RAP.

\begin{tabular}{llcccc}
\hline \multirow{2}{*}{ Mix Type } & \multirow{2}{*}{ Mix Description } & \multicolumn{4}{c}{ Materials $\left(\mathrm{kg} / \mathrm{m}^{3}\right)$} \\
\cline { 3 - 6 } & & Cement & Water & Aggregate & RAP \\
\hline R0 & $100 \%$ virgin aggregates & 364 & 160 & 1902.0 & 0.0 \\
\hline R20 & $80 \%$ virgin aggregates + 20\% RAP aggregates & 364 & 160 & 1521.6 & 380.4 \\
\hline R50 & $50 \%$ virgin aggregates + 50\% RAP aggregates & 364 & 160 & 951.0 & 951.0 \\
\hline R100 & $100 \%$ RAP aggregates & 364 & 160 & 0.0 & 1902.0 \\
\hline
\end{tabular}


TABLE 5. Testing protocols for concrete with RAP.

\begin{tabular}{lcccc}
\hline & \multicolumn{4}{c}{ Hardened concrete properties } \\
\hline & Compressive strength & Flexural strength & Flexural strength & Flexural strength \\
\hline Standard & NCh 1037 & NCh 1038 & NCh 1038 & EN 12697-44 \\
\hline Specimen size $(\mathrm{mm})$ & $150 \times 150 \times 150$ & $150 \times 150 \times 550$ & $75 \times 75 \times 120$ & $100 \times 50 \times 50$ \\
\hline Shape & Cube & Beam & Modified beam & Semi-circular \\
\hline Testing age, $\mathrm{d}$ & $7,14,28$ & $7,14,28$ & $7,14,28$ & $7,14,28$ \\
\hline
\end{tabular}

\subsection{Testing program}

Hardened concrete was tested for compressive strength and flexural strength. Table 5 provides a summary of the tests, ages, and standards. The tests were replicated three times for the samples at each of the different curing times and different RAP contents: a total of 144 specimens tested.

The compressive strength of $150 \mathrm{~mm}$ cubes was measured according to NCh 1037 (34), by testing the specimens at 7,14 , and 28 days of cure at $20 \pm 2^{\circ} \mathrm{C}$ and applying a load rate of $0.35 \mathrm{~N} / \mathrm{m}^{2} / \mathrm{s}$. This research involved evaluating flexural strength using three different specimens: standard beam, modified beam, and Semi-Circular Beam (SCB). The standard specimen for flexural strength testing is normally specified as a $150 \times 150 \times 550 \mathrm{~mm}$ beam. In this case, the flexural strength was measured according to NCh 1038 (35), by applying a third point load at a load application rate of $0.016 \mathrm{~N} / \mathrm{m}^{2} / \mathrm{s}$. It was possible to obtain the so-called modified beam specimens from the standard beam, once tested, using the two halves resulting from the breakage. The $75 \times 75 \times 120 \mathrm{~mm}$ specimens were cut and tested in accordance with NCh 1038 (35), by applying a center point load. The semi-Circular Beams were obtained from the cutting of sliced concrete cylinders, which were cut in half, obtaining specimens that were $100 \mathrm{~mm}$ in diameter, $50 \mathrm{~mm}$ thick and 50 $\mathrm{mm}$ high. Flexural strength for SCB specimens was measured under EN 12697-44 (36), as recommended for asphalt mixtures. The loading application rate for the SCB specimens was $5 \mathrm{~mm} / \mathrm{min}$. Figure 1 shows the different specimens used and the configuration of each of the tests.

\section{RESULTS AND ANALYSIS}

\subsection{Hardened Properties of Concrete}

Figure 2 presents the results of compressive strength and flexural strength, with the relationship between them for the different curing periods of concrete mixes. Error bars indicate standard errors for $95 \%$ confidence. The results show a systematic reduction in the compressive strength of concrete mixtures made with RAP, compared to the control mix; this is consistent with the literature $(13,17,37-39)$.

The reduction in strength could be due to the asphalt layer around the RAP particles being softer than the concrete and aggregate matrix. The presence of a soft binder can induce stress concentration and cause micro-cracking within the concrete matrix. Another possible reason could be the weak link between the asphalt film and the concrete matrix (17). Moreover, compressive strength increases with a longer cure time for the specimens. However, this increase gets smaller as the RAP content in the mixtures increases. Also, the incorporation of RAP into the mixture reduced the flexural strength of the concrete, which is consistent with the literature $(13,18,21)$. The flexural strength reduction pattern presented the same trend as that of compressive strength. However, the rate of strength reduction a) Cube

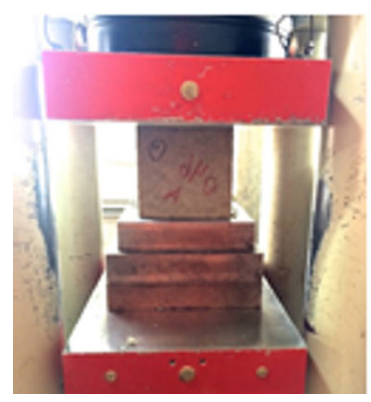

b) Beam

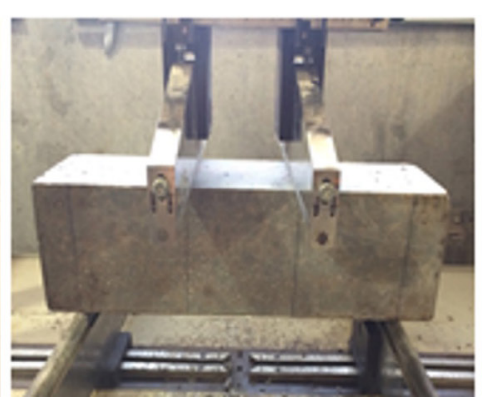

c) SCB

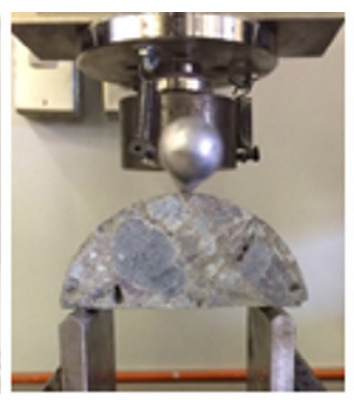

d) Modified beam

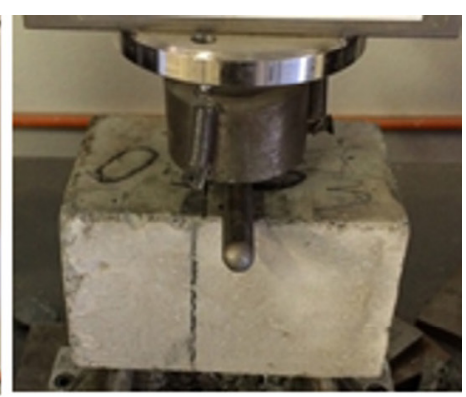

FIGURE 1. Different specimens and mechanical tests. 
a) Beam Specimens
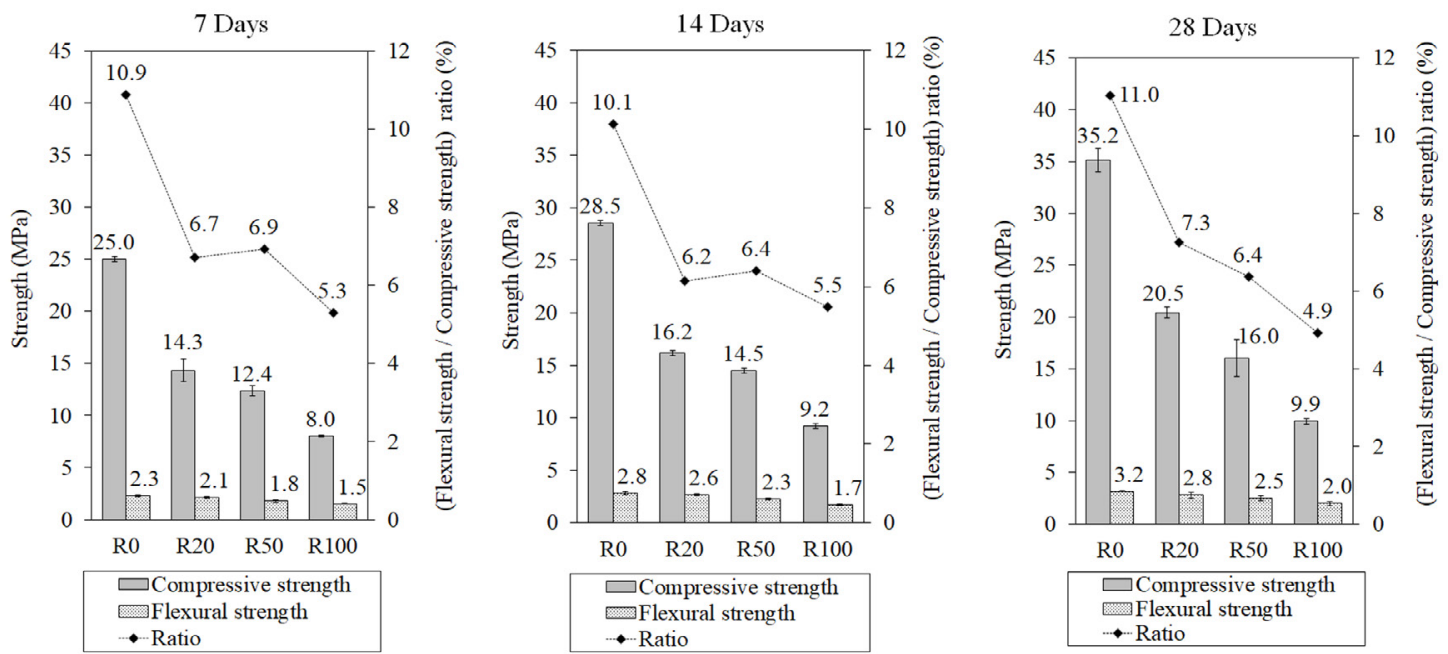

b) SCB Specimens
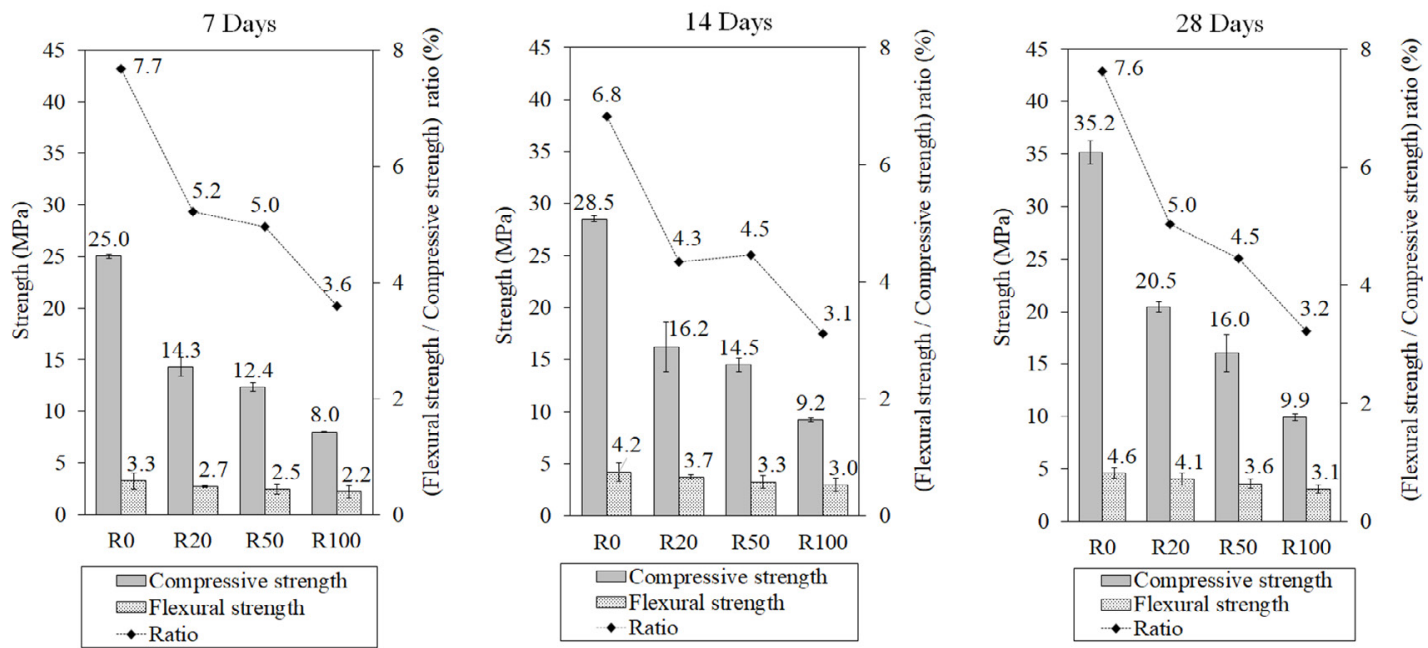

c) Modified Beam Specimens
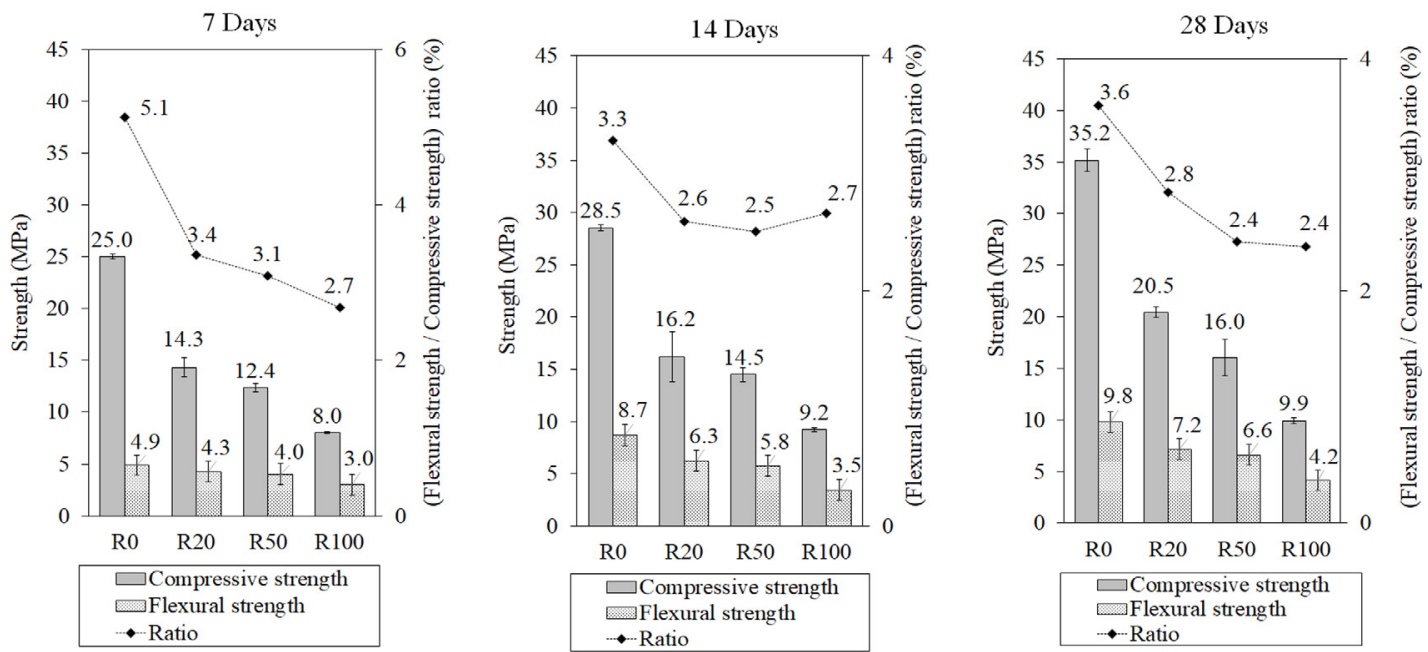

FIGURE 2. Relationship of compressive strength and flexural strength.

Materiales de Construcción 71 (342), April-June 2021, e249. ISSN-L: 0465-2746. https://doi.org/10.3989/mc.2021.11520 
in RAP mixtures was significantly lower than for compressive strength in all test modes. It was also shown that there was a systematic increase in flexural strength with specimen age, for all mixtures. Figure 2 also illustrates the compressive strength to flexural strength ratio. As the RAP content increased, there was a decrease in the strength ratio, which is due to the higher rate of reduction in the concrete's compressive strength, compared to the reduction in its bending strength. These values tend to get closer in all three test specimens, with increasing RAP in the mixtures. For the control mix, the average values of the strength ratio for 7,14 and 28 days' curing of the beam, SCB and modified beam tests were 10.7, 7.4 and 4.0, respectively. This indicates that the relationship depends on the shape of the specimen and RAP content in the mixture.

Figure 3 shows the compressive and flexural strength reductions in mixtures R20, R50, and R100 with respect to the standard mixture, R0. It was observed that the reductions in the studied mixtures' compressive strength at different testing ages were of the same order of magnitude, obtaining an average of $42.6 \%, 51.4 \%$, and $69.1 \%$ for the mixtures R20, R50, and R100, respectively. This indicates that, as the amount of RAP in the mixture increased, the loss of compressive strength also increased, compared to the standard mixture. Compressive strength decreased sharply when using a 20\% RAP replacement rate. Its reduction was higher than $10 \mathrm{MPa}$. As can be seen, for the same mixture at different test ages, the reduction percentage is relatively constant, which suggests that the RAP and cement matrix's chemical bonds do not improve over time. This coincides with the findings reported by (13). A reduction in flexural strength after 28 days of curing can also be seen for all three specimens. As RAP increases, there is a higher flexural strength reduction compared to the standard mixture ( $0 \%$ RAP). This reduction is minor compared to that presented by the compressive strength tests, indicating that the flexural strength property is less affected by the incorporation of RAP aggregates in the mix. It is also possible to observe that the flexural strength depends on the specimen used and the test mode in the laboratory. However, a similarity was found in the flexural strength reduction values for the beam and SCB specimens.

\subsection{Relationship between compressive and flexural strengths}

A regression analysis of the relationship between cubic compressive strength and flexural strength was performed for three different specimens. All curing a) Compressive strength

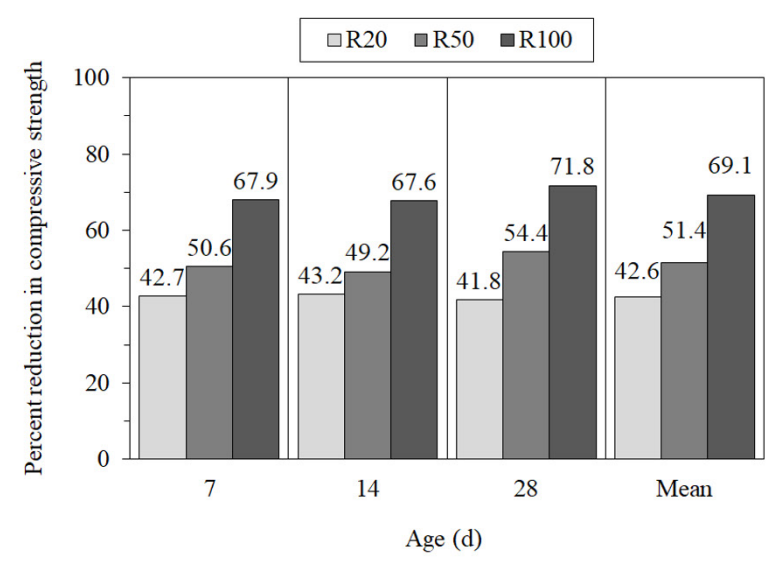

b) Flexural strength at 28 days curing

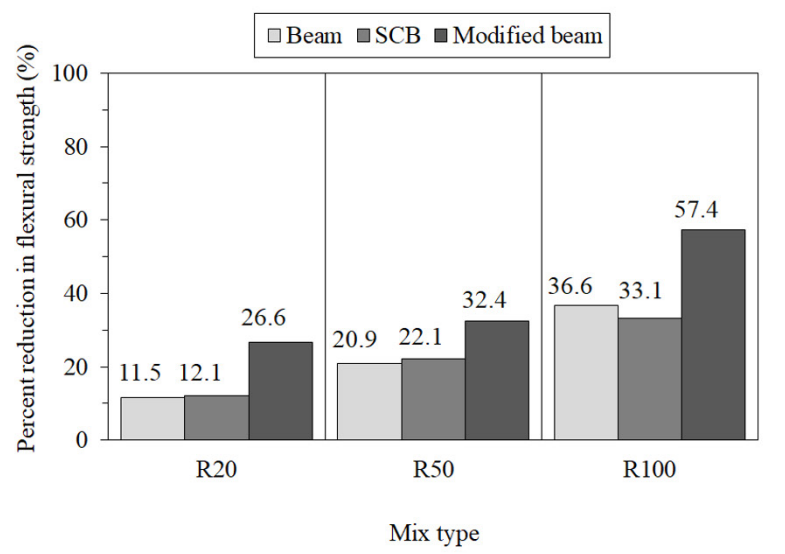

FIGURE 3. Percentage reduction of strength.

TABLE 6. Relationship between compressive and flexural strength.

\begin{tabular}{|c|c|c|c|}
\hline \multirow{2}{*}{ Test mode } & \multicolumn{3}{|c|}{ Model Regression Equations } \\
\hline & Linear & Logarithm & Power \\
\hline Beam & $\begin{aligned} f_{\text {s beam }}=0.0524 & f_{c u} \\
& +1.3894\end{aligned}$ & $\begin{array}{r}f_{s \text { beam }}=0.9948 \ln \left(f_{c u}\right) \\
-0.4438\end{array}$ & $\begin{array}{l}f_{S \text { beam }} \\
=0.6647\left(f_{c u}\right)^{0.4417}\end{array}$ \\
\hline $\mathrm{SCB}$ & $\begin{aligned} f_{S S C B}=0.0712 f_{c u} & \\
& +2.1077\end{aligned}$ & $\begin{aligned} f_{s S C B}=1.3073 & \ln \left(f_{c u}\right) \\
& -0.2603\end{aligned}$ & $\left.f_{S S C B}=1.1173 f_{c u}\right)^{0.39}$ \\
\hline Modif Beam & $\begin{aligned} f_{S M B}=0.2225 f_{c u} & \\
& +1.7863\end{aligned}$ & $\begin{aligned} f_{S M B}=4.0556 & \ln \left(f_{c u}\right) \\
& -5.5312\end{aligned}$ & $\left.f_{S M B}=0.751 f_{c u}\right)^{0.7094}$ \\
\hline
\end{tabular}


periods were taken into account for this analysis. Linear, logarithmic, and power regression models were analyzed to evaluate the prediction equations that best fit the experimental data. From the regression analysis, the equations presented in Table 6 were obtained.

where $f_{\text {s beam }}$ is the flexural strength, obtained from a standardized beam; $f_{S C B}$ is the flexural strength obtained from a semicircular specimen; $f_{S M B}$ is the flexural strength obtained from a beam of smaller dimensions to the standardized beam, and $f_{c u}$ is the cubic compressive strength.

The goodness of fit and the performance of the models were evaluated using statistical procedures. The coefficient of determination $\left(R^{2}\right)$, Pearson correlation coefficient $(r)$, Sum Square Error (SSE), Root Mean Square Error (RMSE), and the Mean Magnitude of the Relative Error $(M M R E)$ of predicted flexural strength to experimental flexural strength values were calculated. Some of these parameters were estimated using Equations [1] to [3]. The lower the SSE and RMSE values, the better the model is at predicting them; values closer to zero indicate a better fit. Furthermore, a model can be considered accurate enough for most purposes when the value of the $M M R E$ parameter is less than 0.25 (40).

$$
\begin{aligned}
& S S E=\sum_{i=1}^{i=n}\left(x_{i}^{*}-x_{i}\right)^{2} \\
& R M S E=\sqrt{\sum_{i=1}^{i=n} \frac{\left(x_{i}^{*}-x_{i}\right)^{2}}{n}} \\
& M M R E=\frac{1}{n} \times \sum_{i=1}^{i=n}\left(\frac{\left|x_{i}-x_{i}^{*}\right|}{x_{i}}\right)
\end{aligned}
$$

where $x_{i}$ is the experimental value observed for data $i, x_{i}^{*}$ is the estimated value for each data $i$ and $n$ is the total number of data.

From Table 7, it can be seen that all $r$ values are greater than 0.8 , which shows a high association strength, indicating that changes in the predictors are related to changes in the response variable and that the obtained prediction models explain much of the variability of the response. It can also be seen that all $M M R E$ values are less than 0.25 for all prediction models, which is considered to be sufficiently accurate, and, therefore, their use is justified. From a general comparison of SSE, RMSE and MMRE, the equations that best fit the experimental data are the logarithmic and power models, considered to be the most suitable for this research. These models allow the estimation of the flexural strength of concrete from its cubic compressive strength, for the range studied in this research. It can also be seen that, for the same value of compressive strength, there is a different value of flexural strength, which indicates that this property depends on the size and shape of the sample and the type of test applied. Figure 4 presents the relationships between the compressive strength of cubes and the flexural strength of concrete using the equations in Table 1 and those obtained in this investigation, described in Table 6. Only power equations are shown for the corresponding comparison. It was observed that the proposed regression equation for the beam specimens coincided with the equation of the ACI-2002, in terms of trend and values. The SCB specimen regression equation shows a similar trend to the equations proposed by IS: 456-200 and Ahmed et al. (4), while the modified beam regression equation shows results much superior to all the equations shown.

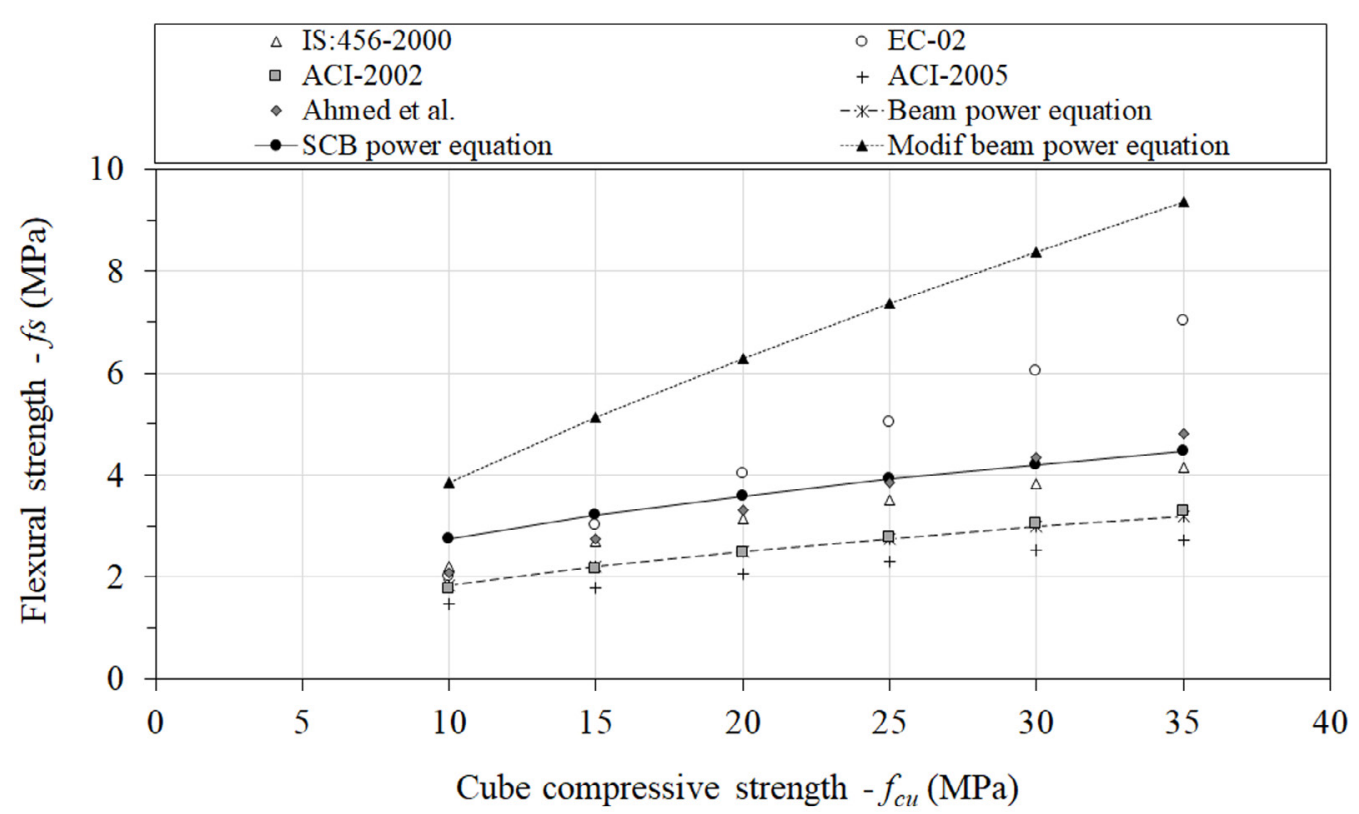

FiguRE 4. Compressive and flexural strength relationship equations. 


\subsection{Relationship between flexural strengths}

Standardized $150 \times 150 \times 550 \mathrm{~mm}$ beams, that can reach a weight of up to $30 \mathrm{~kg}$, have traditionally characterized the flexural strength property of concrete for pavement applications. The flexural strengths were measured from semicircular, smaller beam specimens $(75 \times 75 \times 120 \mathrm{~mm})$ obtained from standardized beams. A possible correlation between the flexural strength values for the three types of specimens was studied. Linear, logarithmic, and power regression models were analyzed to evaluate the prediction equations that best fit the experimental data. From the regression analysis, the equations presented in Table 8 were obtained. The goodness of fit and the perfor- mance of the models were evaluated using the same statistical parameters previously applied. Table 9 shows that all the $r$ values are greater than 0.9 , which means a very high association strength and that the prediction models obtained explain much of the variability of the response. It can also be observed that all MMRE values are less than 0.25 for all prediction models, being considered sufficiently accurate, and their use is justified. From a general comparison of $S S E, R M S E$, and MMRE, the equations that best fit the experimental data are the linear and power models for the SCB specimens. The logarithmic model for the modified beam specimen is the most appropriate in this research. These models allow the estimation of the flexural strength of the concrete beam from SCB

TABLE 7. Comparison of the relations for compressive strength and flexural strength.

\begin{tabular}{|c|c|c|c|c|c|c|c|c|c|c|c|c|c|c|}
\hline \multirow{3}{*}{$\begin{array}{c}\% \\
\text { RAP }\end{array}$} & \multirow{3}{*}{$\begin{array}{c}\text { Age } \\
\text { (days) }\end{array}$} & \multicolumn{4}{|c|}{ Experimental data (MPa) } & \multicolumn{9}{|c|}{ Predicted flexural strength $-f_{s}(\mathrm{MPa})$} \\
\hline & & \multirow{2}{*}{$f_{c u}$ Cube } & \multirow{2}{*}{$\begin{array}{c}f_{S} \\
\text { Beam }\end{array}$} & \multirow{2}{*}{$\begin{array}{c}f_{S} \\
\mathrm{SCB}\end{array}$} & \multirow{2}{*}{$\begin{array}{c}f_{S} \\
\mathrm{MB}\end{array}$} & \multicolumn{3}{|c|}{ Beam model } & \multicolumn{3}{|c|}{ SCB model } & \multicolumn{3}{|c|}{ Modified Beam model } \\
\hline & & & & & & Linear & Logarithm & Power & Linear & Logarithm & Power & Linear & Logarithm & Power \\
\hline \multirow{3}{*}{0} & 7 & 25.03 & 2.30 & 3.26 & 4.88 & 2.70 & 2.76 & 2.76 & 3.89 & 3.95 & 3.92 & 7.36 & 7.53 & 7.37 \\
\hline & 14 & 28.53 & 2.82 & 4.18 & 8.70 & 2.88 & 2.89 & 2.92 & 4.14 & 4.12 & 4.13 & 8.13 & 8.06 & 8.09 \\
\hline & 28 & 35.17 & 3.18 & 4.62 & 9.79 & 3.23 & 3.10 & 3.20 & 4.61 & 4.39 & 4.48 & 9.61 & 8.91 & 9.39 \\
\hline \multirow{3}{*}{20} & 7 & 14.33 & 2.13 & 2.75 & 4.28 & 2.14 & 2.20 & 2.15 & 3.13 & 3.22 & 3.16 & 4.98 & 5.27 & 4.97 \\
\hline & 14 & 16.20 & 2.63 & 3.73 & 6.26 & 2.24 & 2.33 & 2.27 & 3.26 & 3.38 & 3.31 & 5.39 & 5.76 & 5.42 \\
\hline & 28 & 20.45 & 2.82 & 4.06 & 7.18 & 2.46 & 2.56 & 2.52 & 3.56 & 3.69 & 3.63 & 6.34 & 6.71 & 6.39 \\
\hline \multirow{3}{*}{50} & 7 & 12.37 & 1.78 & 2.49 & 4.01 & 2.04 & 2.06 & 2.02 & 2.99 & 3.03 & 2.98 & 4.54 & 4.67 & 4.47 \\
\hline & 14 & 14.50 & 2.27 & 3.25 & 5.79 & 2.15 & 2.22 & 2.17 & 3.14 & 24 & 3.17 & 5.01 & 5.31 & 5.01 \\
\hline & 28 & 16.03 & 2.52 & 3.60 & 6.61 & 2.23 & 2.32 & 2.26 & 3.25 & 3.37 & 3.30 & 5.35 & 5.72 & 5.38 \\
\hline \multirow[t]{8}{*}{100} & 7 & 8.03 & 1.52 & 2.23 & 3.00 & 1.81 & 1.63 & 1.67 & 2.68 & 2.46 & 2.52 & 3.57 & 2.92 & 3.29 \\
\hline & 14 & 9.23 & 1.68 & 2.97 & 3.47 & 1.87 & 1.77 & 1.77 & 2.77 & 2.65 & 2.66 & 3.84 & 3.48 & 3.63 \\
\hline & 28 & 9.93 & 2.02 & 3.09 & 4.17 & 1.91 & 1.84 & 1.83 & 2.81 & 2.74 & 2.74 & 4.00 & 3.78 & 3.83 \\
\hline & & & & & $r$ & 0.859 & 0.896 & 0.890 & 0.834 & 0.841 & 0.827 & 0.877 & 0.878 & 0.883 \\
\hline & & & & & $R^{2}$ & 0.738 & 0.803 & 0.793 & 0.695 & 0.708 & 0.684 & 0.769 & 0.771 & 0.780 \\
\hline & & & & & $S S E$ & 0.745 & 0.559 & 0.631 & 1.698 & 1.626 & 1.623 & 11.388 & 11.257 & 11.138 \\
\hline & & & & & RMSE & 0.249 & 0.216 & 0.229 & 0.376 & 0.368 & 0.368 & 0.974 & 0.969 & 0.963 \\
\hline & & & & & $M M R E$ & 0.097 & 0.080 & 0.085 & 0.106 & 0.103 & 0.105 & 0.150 & 0.132 & 0.141 \\
\hline
\end{tabular}

TABLE 8. Experimental model equations between flexural strength modes.

\begin{tabular}{|c|c|c|}
\hline \multirow{2}{*}{ Model } & \multicolumn{2}{|c|}{ Model Regression Equations } \\
\hline & Linear & Logarithm \\
\hline Beam & $f_{\text {s beam }}=0.6861 f_{S S C B}+0.0053$ & $f_{\text {s beam }}=0.2305 f_{\text {s MB }}+0.997$ \\
\hline SCB & $\begin{array}{c}f_{\text {s beam }}=2.2408 \ln \left(f_{S S C B}\right) \\
-0.358\end{array}$ & $f_{\text {s beam }}=1.3495 \ln \left(f_{S M B}\right)+0.0462$ \\
\hline Modif Beam & $f_{\text {s beam }}=0.6897\left(f_{s S C B}\right)^{0.9958}$ & $f_{\text {s beam }}=0.8265\left(f_{s M B}\right)^{0.5989}$ \\
\hline
\end{tabular}


TABLE 9. Comparison of the relation for flexural strengths.

\begin{tabular}{|c|c|c|c|c|c|c|c|c|c|c|}
\hline \multirow{3}{*}{$\%$ RAP } & \multirow{3}{*}{ Age (days) } & \multicolumn{3}{|c|}{$\begin{array}{l}\text { Experimental data of flexural } \\
\text { strength }-f_{s}(\mathrm{MPa})\end{array}$} & \multicolumn{6}{|c|}{ Predicted flexural strength $-f_{s}(\mathrm{MPa})$} \\
\hline & & \multirow{2}{*}{ Beam } & \multirow{2}{*}{$\mathrm{SCB}$} & \multirow{2}{*}{ Modified beam } & \multicolumn{3}{|c|}{ SCB model } & \multicolumn{3}{|c|}{ Modified Beam model } \\
\hline & & & & & Linear & Logarithm & Power & Linear & Logarithm & Power \\
\hline \multirow{3}{*}{0} & 7 & 2.30 & 3.26 & 4.88 & 2.24 & 2.29 & 2.24 & 2.12 & 2.19 & 2.14 \\
\hline & 14 & 2.82 & 4.18 & 8.70 & 2.87 & 2.85 & 2.87 & 3.00 & 2.97 & 3.02 \\
\hline & 28 & 3.18 & 4.62 & 9.79 & 3.17 & 3.07 & 3.16 & 3.25 & 3.12 & 3.24 \\
\hline \multirow{3}{*}{20} & 7 & 2.13 & 2.75 & 4.28 & 1.89 & 1.91 & 1.89 & 1.98 & 2.01 & 1.97 \\
\hline & 14 & 2.63 & 3.73 & 6.26 & 2.56 & 2.59 & 2.56 & 2.44 & 2.52 & 2.48 \\
\hline & 28 & 2.82 & 4.06 & 7.18 & 2.79 & 2.78 & 2.78 & 2.65 & 2.71 & 2.69 \\
\hline \multirow{3}{*}{50} & 7 & 1.78 & 2.49 & 4.01 & 1.72 & 1.69 & 1.71 & 1.92 & 1.92 & 1.90 \\
\hline & 14 & 2.27 & 3.25 & 5.79 & 2.24 & 2.29 & 2.23 & 2.33 & 2.42 & 2.37 \\
\hline & 28 & 2.52 & 3.60 & 6.61 & 2.47 & 2.51 & 2.47 & 2.52 & 2.59 & 2.56 \\
\hline \multirow[t]{8}{*}{100} & 7 & 1.52 & 2.23 & 3.00 & 1.54 & 1.44 & 1.54 & 1.69 & 1.53 & 1.60 \\
\hline & 14 & 1.68 & 2.97 & 3.47 & 2.04 & 2.08 & 2.04 & 1.80 & 1.73 & 1.74 \\
\hline & 28 & 2.02 & 3.09 & 4.17 & 2.12 & 2.17 & 2.12 & 1.96 & 1.97 & 1.94 \\
\hline & & & & $r$ & 0.960 & 0.952 & 0.947 & 0.959 & 0.977 & 0.970 \\
\hline & & & & $R^{2}$ & 0.923 & 0.907 & 0.896 & 0.920 & 0.954 & 0.941 \\
\hline & & & & $S S E$ & 0.220 & 0.265 & 0.221 & 0.228 & 0.130 & 0.177 \\
\hline & & & & RMSE & 0.135 & 0.149 & 0.136 & 0.138 & 0.104 & 0.121 \\
\hline & & & & MMRE & 0.046 & 0.051 & 0.046 & 0.057 & 0.041 & 0.049 \\
\hline
\end{tabular}

or Modified Beam specimen tests. It is possible to observe that the values predicted by the linear, logarithmic, and potential models for the SCB and modified beam test specimens are close to those obtained in the laboratory for the flexural strength of a standardized beam. This indicates a relationship between the flexural strength values that is independent of the shape of the specimens tested and that allows the estimation of this property for a standard-size beam, using smaller specimens that are easily manipulated and consume less materials.

\section{CONCLUSIONS}

A laboratory study was developed to evaluate the mechanical properties of concrete with and without the incorporation of RAP. Cube compression strength and flexural strength tests were carried out, applying three test modes representing different shapes and sizes of specimens (beam, SCB, and modified beam). Based on the analysis of the test results, it is possible to draw the following conclusions:

Compressive strength and flexural strength decrease with increasing RAP in the mix. Compressive strength decreases dramatically from $20 \%$ RAP incorporation. The flexural strength for all three-test modes decreases steadily with RAP incorporation into the mixture. It can be considered a less susceptible property compared to the compressive strength. The flexural strength depends on the shape and size of the specimen and the type of test.

Representative equations are proposed to relate the compressive strength properties to the flexural strength for the three test specimens. This relationship depends on the shape of the test specimen used and the amount of RAP incorporated in the mixture, but it is considered to be constant during the curing time. The logarithmic and power models are the most appropriate and accurate to use. For these models, the Pearson correlation coefficient between the two types of strength is greater than 0.80 , which indicates that they are well-correlated and fit satisfactorily with the experimental data.

The power equation proposed to relate the compressive strength and the flexural strength of standardized beams shows the same trend as the equation proposed by ACI-2002, practically obtaining the same results.

In this research, correlation equations are proposed between flexural strengths for the three types of tests used. Linear and power models are suggested for tests with SCB specimens and a logarithmic model for tests with modified specimens. These models have a Pearson correlation coefficient higher than 0.9, which means a very high association of strength and explains a large part of the variability of the response, 
indicating that they are the most adequate and accurate to represent the experimental data. The models can be used to estimate the flexural strength of concrete obtained for a standardized beam from the values obtained in the laboratory using more easily manipulated and safer specimens, both in the laboratory and in the field.

\section{REFERENCES}

1. ICPA - Instituto del Cemento Portland Argentino. (2014) Manual de diseño y construcción de pavimentos de hormigón, ISBN 978-950-677-003-7, Buenos Aires, Argentina, (2014).

2. NRMCA - National Ready Mixed Concrete Association. (2000) CIP 16- Flexural Strength Concrete. Concrete in Practice, https://www.nrmca.org/wp-content/ uploads/2020/04/16pr.pdf.

3. Yusuf, I.T.; Jimoh, Y.A.; Salami, W.A. (2016) An appropriate relationship between flexural strength and compressive strength of palm kernel shell concrete. Alexandria Eng. J. 55 [2], 1553-1562. https://doi.org/10.1016/j.aej.2016.04.008.

4. Ahmed, M.; El Hadi, K.M.; Hasan, M.A.; Mallick, J.; Ahmed, A. (2014) Evaluating the co-relationship between concrete flexural tensile strength and compressive strength. Int. J. Struct. Eng. 5 [2], 115-131. https://doi.org/10.1504/IJSTRUCTE.2014.060902.

5. Xiao, J-Zh.; Li, J-B.; Zhang, C. (2006) On relationships between the mechanical properties of recycled aggregate concrete: An overview. Mater. Struct. 39, 655-664. https://doi. org/10.1617/s11527-006-9093-0.

6. Ismeik, M. (2009) Effect of mineral admixtures on mechanical properties of high strength concrete made with locally available materials. Jordan. J. Civ. Eng. 3 [1], 78-90. https://www.iiste.org/Journals/index.php/JJCE/article/ view/17874/18251

7. Ahmed, M.; Dad Khan, M.K.; Wamiq, M. (2008) Effect of concrete cracking on the lateral response of RCC buildings. Asian J. Civ. Eng. (Building Housing). 9 [1], 25-34. https:// www.sid.ir/En/Journal/ViewPaper.aspx?ID=108211.

8. Uchechukwu, A.; Kabir, N. (2019) Flexural strength and compressive strength relations of spent foundry sand concrete. ACI Mater. J. 116 [6], 205-211. https://doi. org/10.14359/51718055.

9. Bhanja, S.; Sengupta, B. (2005) Influence of silica fume on the tensile strength of concrete. Cem. Concr. Res. 35 [4], 743-747. https://doi.org/10.1016/j.cemconres.2004.05.024.

10. Chhorn, C.; Hong, S.J.; Lee, S.W. (2018) Relationship between compressive and tensile strengths of roller-compacted concrete. J. Traffic Transp. Eng. 5 [3], 215-223. https://doi. org/10.1016/j.jtte.2017.09.002.

11. Pacheco, J.N.; de Brito, J.; Chastre, C.; Evangelista, L. (2019) Probabilistic conversion of the compressive strength of cubes to cylinders of natural and recycled aggregate concrete specimens. Materials. 12 [2], 280. https://doi.org/10.3390/ ma12020280

12. Dirección de Vialidad. (2020) Red Vial Nacional-Dimensionamiento y Características. Ministerio de Obras Públicas. http://www.vialidad.cl/areasdevialidad/gestionvial/Documents/RedVialNacional2019.pdf

13. Brand, A.S.; Roesler, J.R. (2015) Ternary concrete with fractionated reclaimed asphalt pavement. ACI Mater. J. 112 [1], 155-164. https://doi.org/10.14359/51687176.

14. Copeland, A. (2011) Reclaimed asphalt pavement in asphalt mixtures: state of the practice. Rep No FHWA-HRT-11-021, Federal Highway Administration (FHWA), McLean, Virginia. https://www.fhwa.dot.gov/publications/research/infrastructure/pavements/11021/11021.pdf

15. Shi, X.; Mukhopadhyay, A.; Liu, K-W. (2017) Mix design formulation and evaluation of Portland cement concrete paving mixtures containing reclaimed asphalt pavement. Constr. Build. Mater. 152, 756-768. https://doi.org/10.1016/j.conbuildmat.2017.06.174.
16. MOP - DGOP. (2019) Manual de carreteras de Chile. Vol. 5. Santiago de Chile, Ministerio de Obras Públicas de Chile, 2019.

17. Huang, B.; Shu, X.; Li, G. (2005) Laboratory investigation of Portland cement concrete containing recycled asphalt pavements. Cem. Concr. Res. 35 [10], 2008-2013. https://doi. org/10.1016/j.cemconres.2005.05.002.

18. Singh, S.; Ransinchung, G.D.; Kumar, P. (2017) An economical processing technique to improve RAP inclusive concrete properties. Constr. Build. Mater. 148, 734-747. https://doi. org/10.1016/j.conbuildmat.2017.05.030

19. Berry, M.; Stephens, J.; Bermel, B.; Hagel, A.; Schroeder, D. (2013) Feasibility of reclaimed asphalt pavement as aggregate in Portland cement concrete pavements. FHWA/MT-13009/8207. https://rosap.ntl.bts.gov/view/dot/24948.

20. Brand, A.S.; Amirkhanian, A.N.; Roesler, J.R. (2014) Flexural capacity of full-depth and two-lift concrete slabs with recycled aggregates. Transp. Res Rec. 2456, 64-72. https://doi. org/10.3141/2456-07.

21. Hossiney, N.; Tia, M.; Bergin, M.J. (2010) Concrete containing RAP for use in concrete pavement. Int. J. Pavem. Res. Technol. 3 [5], 251-258. http://www.ijprt.org.tw/files/sample/V3N5\%284\%29.pdf.

22. Erdem, S.; Blankson, M.A. (2014) Environmental performance and mechanical analysis of concrete containing recycled asphalt pavement (RAP) and waste precast concrete as aggregate. J. Hazard. Mater. 264, 403-410. https://doi. org/10.1016/j.jhazmat.2013.11.040.

23. Ben Saïd, S.E.E.; El Euch Khay, S.; Achour, T.; Loulizi, A. (2017) Modelling of the adhesion between reclaimed asphalt pavement aggregates and hydrated cement paste. Constr. Build. Mater. 152, 839-846. https://doi.org/10.1016/j.conbuildmat.2017.07.078.

24. Getahun, M.A.; Shitote, S.M.; Gariy, Z.C.A. (2018) Experimental investigation on engineering properties of concrete incorporating reclaimed asphalt pavement and rice husk ash. Buildings. 8 [9], 115. https://doi.org/10.3390/buildings8090115.

25. Chyne, J.M.; Sepuri, H.K.; Thejas, H.K. (2019) A review on recycled asphalt pavement in cement concrete. Int. J. Latest Eng. Res. Appl. 4 [2], 9-18. http://www.ijlera.com/papers/v4i2/2.201902010.pdf.

26. Singh, S.; Ransinchung, G.D.R.N.; Kumar, P. (2019) Feasibility study of RAP aggregates in cement concrete pavements. Road Mater. Pavem. Des. 20 [1], 151-170. https://doi.org/10 .1080/14680629.2017.1380071.

27. Al-Mufti, R.L.; Fried, A.N. (2017) Improving the strength properties of recycled asphalt aggregate concrete. Constr. Build. Mater. 149, 45-52. https://doi.org/10.1016/j.conbuildmat.2017.05.056.

28. Singh, S.; Ransinchung, G.D.R.N. (2020) Laboratory and field evaluation of RAP for cement concrete pavements. $J$. Transp. Eng. 146 [2], 1-11. https://doi.org/10.1061/JPEODX.0000162.

29. Shi, X.; Mukhopadhyay, A.; Zollinger, D.; Huang, K. (2021) Performance evaluation of jointed plain concrete pavement made with portland cement concrete containing reclaimed asphalt pavement. Road Mater. Pavem. Des. 22 [1], 59-81. https://doi.org/10.1080/14680629.2019.1616604.

30. NCh1498 (2012) Concrete and mortar - Mixing water - Classification and requirements. Chilean Standard.

31. NCh170 (1985) Concrete - General requirement. Chilean standard.

32. Ministry of Housing and Urbanism. (2018) Código de normas y especificaciones técnicas de obras de pavimentación, Editora e imprenta MAVAL S.P.A., Santiago de Chile, 1-340 p, (2018).

33. NCh1017 (2009) Concrete-Making in the field and curing specimens for compression, flexural and spitting tensile tests. Chilean Standard.

34. NCh 1037 (2009) Concrete - Test for compressive strength of molded cubes and cylinders. Chilean Standard.

35. NCh1038 (2009) Concrete - Test for flexural tensile strength. Chilean Standard.

36. EN 12697-44 (2011) Bituminous mixtures - Test methods - Part 44: Crack propagation by semi-circular bending test. Spanish standard. 
Empirical relationships between compressive and flexural strength of concrete containing recycled asphalt material for pavement... 11

37. Al-Mufti, R.L.; Fried, A.N. (2017) Improving the strength properties of recycled asphalt aggregate concrete. Constr. Build. Mater. 149, 45-52. https://doi.org/10.1016/j.conbuildmat.2017.05.056.

38. El Euch Ben Said, S.; El Euch Khay, S.; Loulizi, A. (2018) Experimental investigation of PCC incorporating RAP. Int. J. Concr. Struct. Mater. 12, 8. https://doi.org/10.1186/s40069018-0227-x
39. Abraham, S.M.; Ransinchung, G.D.R.N. (2018) Influence of RAP aggregates on strength, durability and porosity of cement mortar. Constr. Build. Mater. 189, 1105-1112. https:// doi.org/10.1016/j.conbuildmat.2018.09.069.

40. Ardiansyah, A.; Mardhia, M.M.; Handayaningsih, S. (2018) Analogy-based model for software project effort estimation. Int. J. Adv. Intell. Informatics. 4 [3], 251-260. http://doi. org/10.26555/ijain.v4i3.266. 